\title{
Penyerapan Tenaga Kerja Industri Provinsi Jawa Timur: Apakah Upah Minimum Masih Menjadi Faktor Penentu?
}

\section{Jurnal Ecces}

\author{
Atu Bagus Wiguna ${ }^{1}$ \\ ${ }^{1}$ Jurusan Ilmu Ekonomi \\ Fakultas Ekonomi dan Bisnis Universitas Brawijaya \\ Jl. MT. Haryono No.165, Ketawanggede, Kec. Lowokwaru, Kota Malang, Jawa Timur (65300) \\ E-mail: atu@ub.ac.id
}

\section{Abstrak: Penyerapan Tenaga Kerja Industri Provinsi Jawa Timur: Apakah Upah Minimum Masih Menjadi Faktor Penentu?}

Model standar pasar tenaga kerja kompetitif memprediksi upah minimum sebagai faktor penentu penyerapan tenaga kerja. Dengan tren peningkatan upah minimum dan kinerja industri, penyerapan tenaga kerja masih mengalami fluktuasi. Penelitian ini bertujuan untuk menganalisis fakor - faktor yang mempengaruhi penyerapan tenaga kerja industri di provinsi Jawa Timur, Indonesia. Menggunakan data level Kabupaten / Kota, persamaan penyerapan tenaga kerja diestimasi dengan regresi data panel. Ditemukan bahwa penyerapan tenaga kerja industri dipengaruhi oleh PDRB (Produk Domestik Regional Bruto) industri; sedangkan upah minimum tidak menjadi indikator utama yang mempengaruhi penyerapan tenaga kerja seiring dengan implementasi kebijakan pengupahan di Indonesia yang mempertimbangkan PDB (Produk Domestik Bruto) dan inflasi. Implikasi dari temuan ini, pada wilayah dengan PDRB tinggi perlu fokus pada perbaikan kualitas tenaga kerja untuk meminimalisir shifting antara tenaga kerja dan modal; sedangkan wilayah dengan PDRB rendah perlu mempercepat pembangunan kawasan industri baru agar dapat menampung tren relokasi dan perpindahan tenaga kerja.

Kata Kunci: Penyerapan Tenaga Kerja, Upah Minimum, PDRB Industri

\section{Abstract: Industrial Employment in East Java Province: Does Minimum Wage Still Considered as The First Determinant?}

Standard Competitive labor Market Model predicts the minimum wage as the first determinant in labor market condition. Yet, the increasing trend of minimum wage and industrial performance still followed by fluctuated employment. This research aims to analyze factors that could affect Industrial Employment di East Java province, Indonesia. Utilizing sub-province panel data, the equation executed using regression method. This research found that industrial employment affected by GRDP (Gross Domestic Regional Bruto) for industrial sector; meanwhile, the minimum wage is not being the first determinant 
for industrial employment as the Indonesian Government Regulation decides minimum wage based on GDP (Gross Domestic Bruto) and inflation. This research implies that a region with high level of GDRP needs to focus on quality improvement of the labor; meanwhile, a region with low level of GRDP needs to focus on accelerating the development of industrial estate (Kawasan industri) for preparing labor and industrial relocation.

Keywords: Industrial Employment, Minimum Wage, Industry's GRDP .

\section{PENDAHULUAN / INTRODUCTION}

Provinsi Jawa Timur merupakan salah satu provinsi di Pulau Jawa yang menjadi salah satu wilayah dengan tingkat pertumbuhan ekonomi terbesar di Indonesia. Kondisi tersebut tergambarkan pada gambar 1 di mana perekonomian Provinsi Jawa Timur yang berkembang didukung pula oleh oleh kinerja industri yang tinggi.

Gambar 1. Gambaran Kinerja Perekonomian Prov. Jawa timur Berdasarkan PDRB

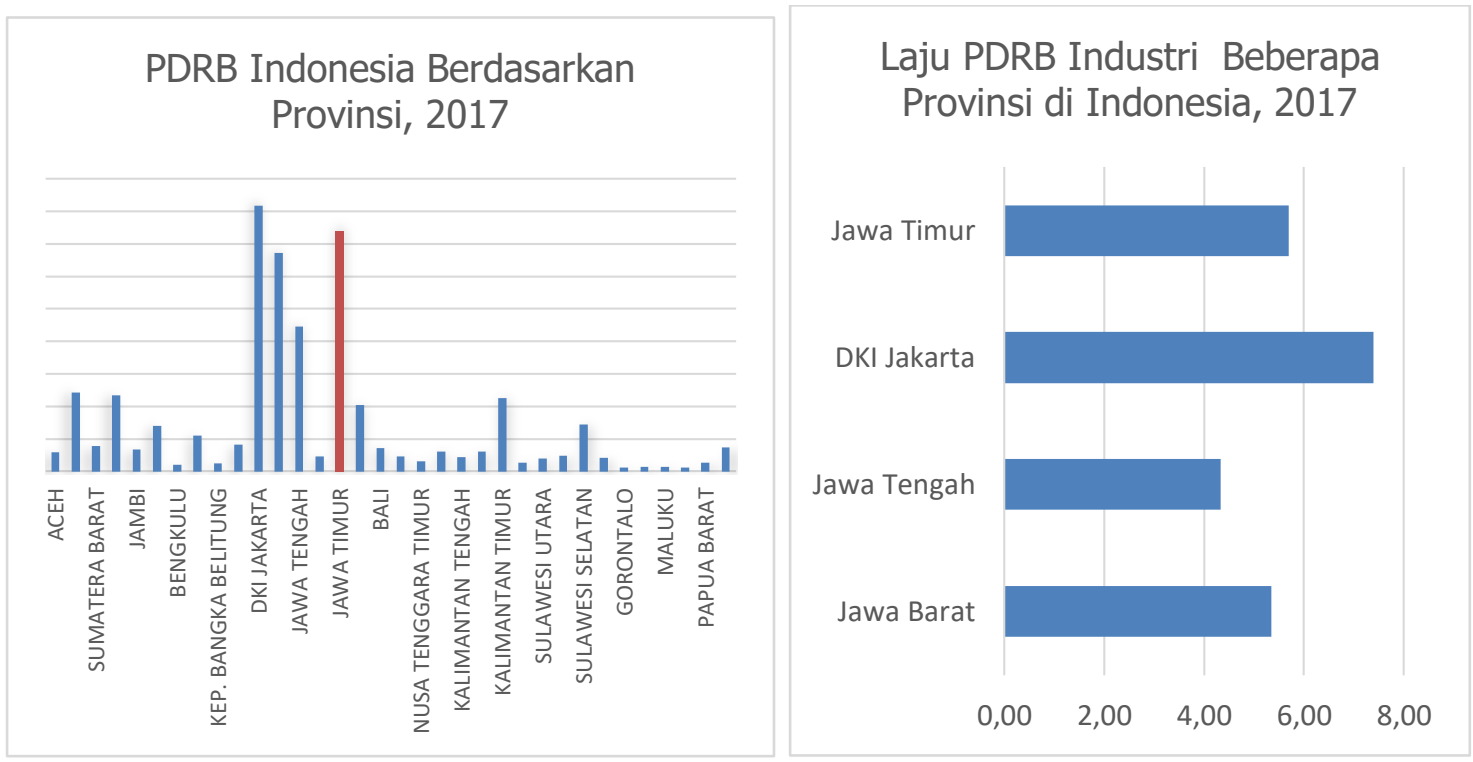

Sumber: BPS, diolah (2019)

Kinerja tersebut, belum sejalan dengan penyerapan tenaga kerja. Secara keseluruhan terdapat fluktuasi penyerapan tenaga kerja yang cukup tinggi selama tahun 2012 sampai dengan 2017. Tenaga kerja yang terserap berkurang hingga tahun 2016, namun kembali meningkat di akhir tahun amatan (lihat gambar 2). Gejolak tersebut tidak berjalan searah dengan giatnya sektor industri yang berkembang secara pesat. 
Gambar 2. Penyerapan tenaga Kerja Industri di Prov. Jawa Timur, 2012-2017

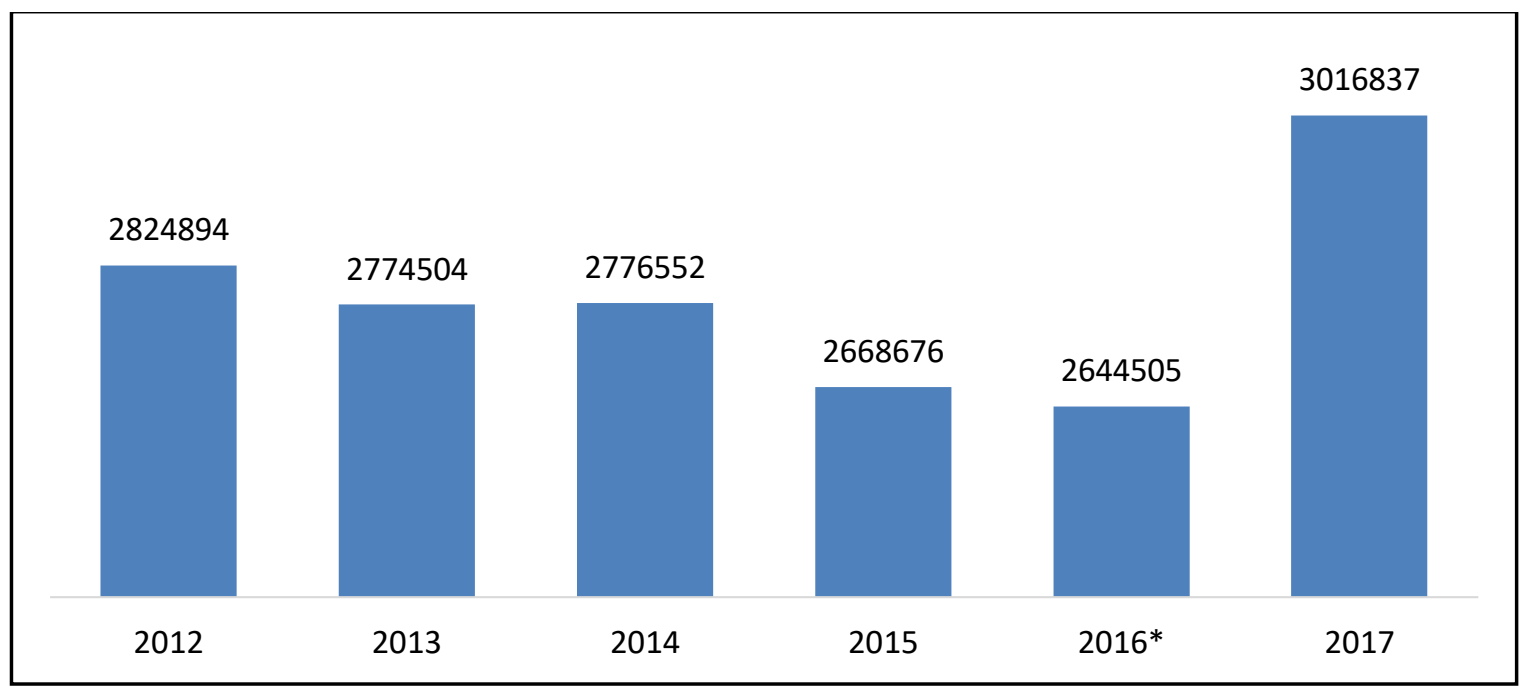

*interpolasi data oleh penulis

Sumber: Keadaan Angkatan Kerja Jawa Timur, badan pusat Statistik, data dioleh (2019)

Secara lebih terperinci, gambar 3 menunjukan beberapa indikator kinerja Provinsi Jawa Timur yang terkait dengan pasar tenaga kerja dan kinerja industri. Dari segi supply of labor, tampak terdapat perbaikan kualitas tenaga kerja dengan meningkatnya tenaga kerja terdidik. Dari segi demand of labor, jumlah unit dan nilai tambah industri kian meningkat.

Gambar 3. Beberapa Indikator Perekonomian Jawa Timur Terkait Tenaga Kerja da Industri, 2009-2017

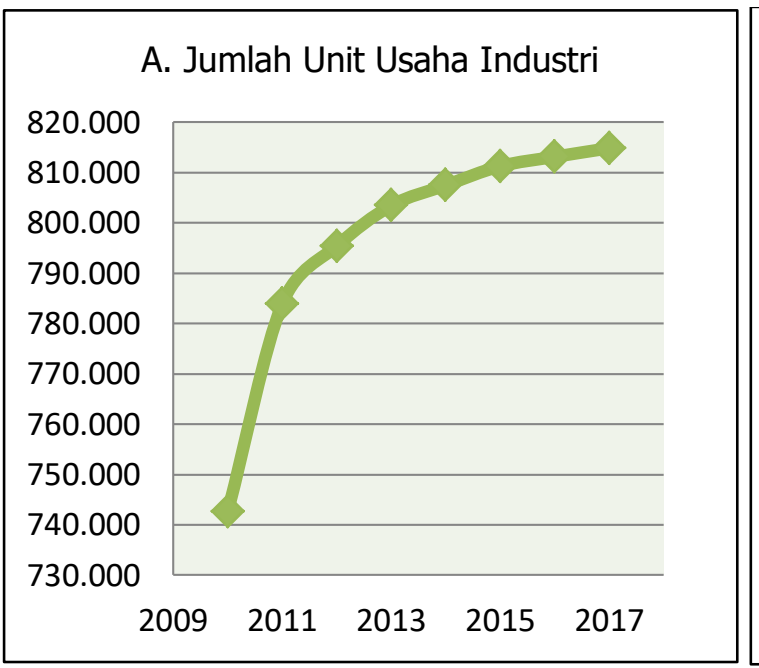

B. Nilai Produksi Industri (Milyar)

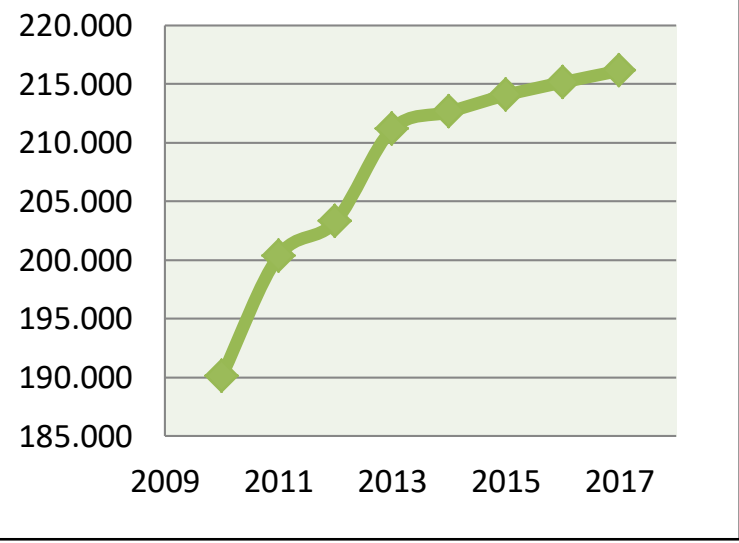



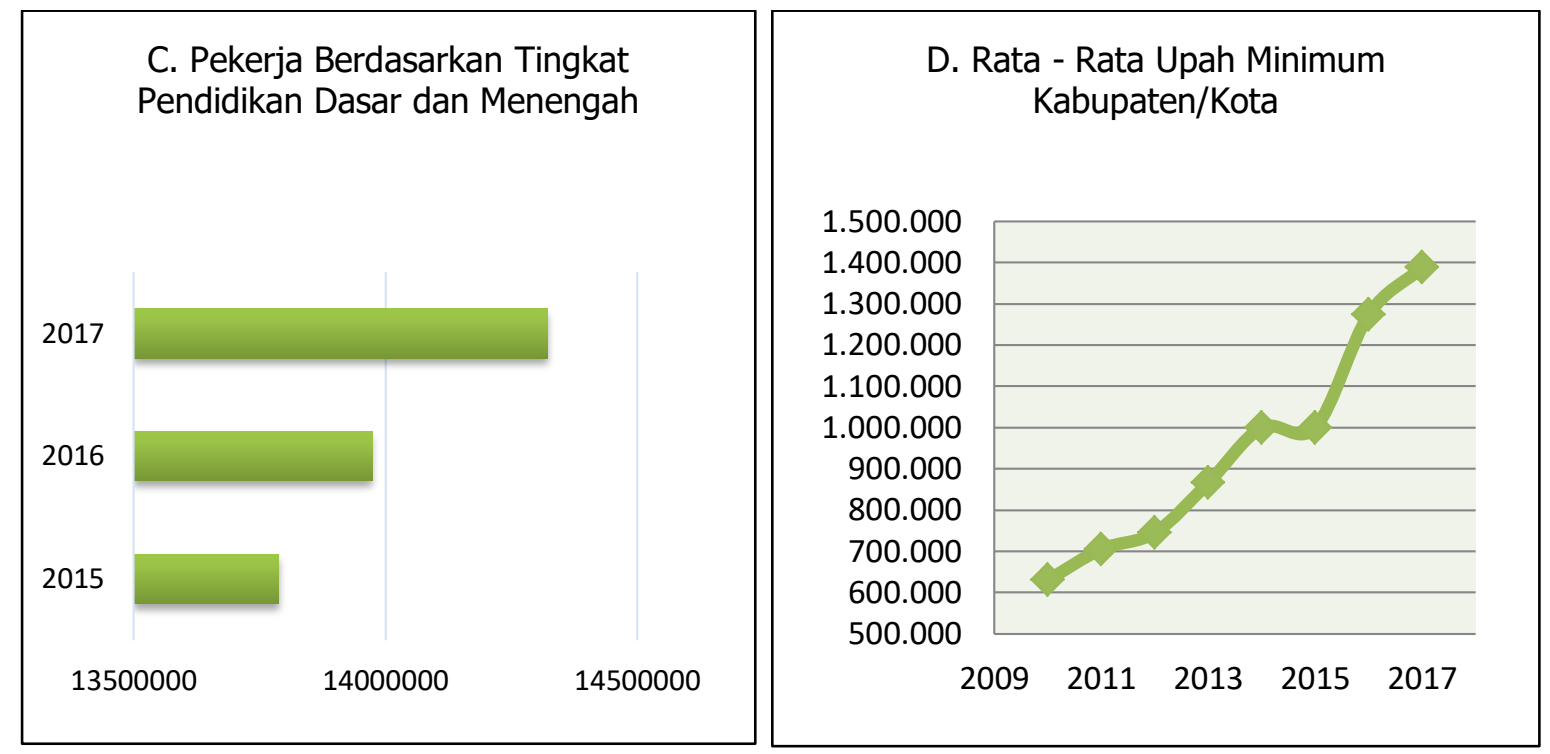

Sumber: Jawa Timur Dalam Angka, Badan Pusat Statistik, data diolah (2019)

Adapun dari segi upah minimum (gambar 3D), hubungan antara upah minimum dan jumlah pekerja industri di Provinsi Jawa Timur relatif ambigu. Tampak bahwa perkembangan upah minimum diikuti oleh betambahnya jumlah tenaga kerja (gambar 2), di mana hubungan tersebut berlawanan dengan standard competitive model pasar tenaga kerja yang meyakini adanya hubungan yang bertolak belakang antara upah minimum dan penyerapan tenaga kerja (Ehrenberg dan Smith, 2012; Borjas, 2016).

Disisi lain, sektor industri sebagai leading sector pada perekonomian Jawa Timur diharapkan mampu mendukung terciptanya kesejahteraan dengan membuka peluang kesempatan kerja atau penyerapan tenaga kerja. Hal tersebut sesuai dengan model produksi standar yang menyatakan bahwa besarnya jumlah output produksi didorong oleh tambahan faktor input berupa tenaga kerja dan modal (Nicholson dan Synder, 2010). Namun demikian, faktanya perkembangan sektor industri dengan semakin banyaknya jumlah unit usaha, nilai produksi, serta tingkat upah minimum yang terus meningkat tidak mampu menjadikan sektor tersebut mampu mengoptimalkan penyerapan tenaga kerja secara optimal karena daya serap yang masih berfluktuasi. Oleh karena itu, penelitian disusun untuk menganalisis faktor - faktor yang mempengaruhi penyerapan tenaga kerja pada sektor industri di Provinsi Jawa Timur. 


\section{TINJAUAN TEORITIK / LITERATURE REVIEW}

\section{Penyerapan Tenaga Kerja dan Upah Minimum}

Konsep teoretis mengenai penyerapan tenaga kerja, dengan asumsi terdapat pergerakan upah minimum, sejauh ini dijelaskan oleh model standar pasar tenaga kerja kompetitif Stigler yang menyatakan penyerapan tenaga kerja dipengaruhi oleh upah minimum ditentukan oleh upah minimum sebagai variabel utama (Borjas, 2016). Melalui konsep tersebut diketahui bahwa upah minimum memberikan sinyal bagi pasar, di mana meningkatnya upah minimum membuat berkurangnya penyerapan tenaga kerja sebagai akibat respon permintaan tenaga kerja yang berupaya mengurangi ongkos produksi.

\section{Gambar 4. Efek Upah Minimum Terhadap Penyerapan Tenaga Kerja}

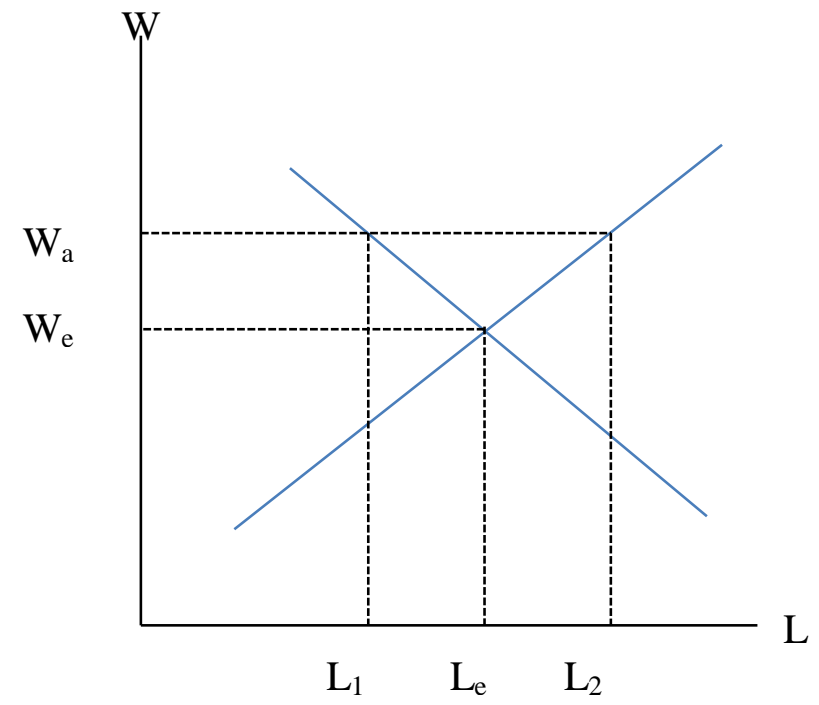

Sumber: Borjas, 2016

Gambar 4 menjelaskan model standar pasar tenaga kerja dimana $W$ adalah upah dan $L$ adalah jumlah tenaga kerja yang dipekerjakan (dalam kontek penelitian ini merupakan penyerapan tenaga kerja industri). Titik keseimbangan pasar adalah $W_{e}, L_{e}$, di mana jika terjadi peningkatan upah minimum dari $\mathrm{W}_{\mathrm{e}}$ ke $\mathrm{W}_{\mathrm{a}}$ maka dampaknya 1 ) terjadi peningkatan angka pengangguran sebesar $L_{1}-L_{e}$ bagi tenaga kerja yang ada di pasar tersebut; dan 2) terjadi exess supply tenaga kerja baru sebagai akibat minat partisipasi kerja di pasar tersebut meningkat.

Kemudian penyerapan tenaga kerja dengan mempertimbangkan adanya perluasan output dapat dijelaskan oleh fungsi produksi perusahaan (Nicholson dan Synder, 2010; 
Atu Bagus Wiguna. Penyerapan Tenaga Kerja Industri ...

Borjas, 2016). Beberapa persamaan yang dapat menggambarkan kondisi pernyerapan tenaga kerja adalah sebagai berikut:

$$
\begin{aligned}
& \text { 1) } Q=f\left(L, K_{0}\right) \\
& \text { 2) } V A P=p \times A P
\end{aligned}
$$

Di mana, $\mathrm{Q}$ adalah total produksi perusahaan; $\mathrm{L}$ adalah jumlah input tenaga kerja; $\mathrm{K}_{0}$ adalah jumlah input modal yang dianggap konstan; VMP adalah value of Marginal product; MP adalah marginal product; $\mathrm{p}$ adalah tingkat harga. Melalui 2 persamaan diatas, dapat dijeaskan bahwa 1) Perluasan output produksi akan mendorong perusahaan untuk meningkatkan permintaan tenaga kerja; 2) dengan adanya prinsip the law of diminishing returns, perusahaan akan mempekerjakan tenaga kerja hingga pada kondisi value of marginal product sama dengan tingkat upah (sebagai representasi ongkos dari mempekerjakan tenaga kerja).

Selanjutnya, penyerapan tenaga kerja dengan mempertimbangkan supply of labor menjelaskan adanya efek subsitusi dan efek pendapatan dari peningkatan upah minimum (Ehrenberg dan Smith, 2012; Borjas, 2016). Efek substitusi mendominasi ketika tenaga kerja memilih meningkatkan jam kerja seiring dengan meningkatnya upah; disisi lain, efek pendapatan mendominasi ketika tenaga kerja memilih mengurangi jam kerja seiring dengan meningkatnya upah.

Penyerapan tenaga kerja serta kaitannya dengan upah minimum dan kinerja industri menunjukan hasil yang tidak konsisten (Card dan Krueger, 1994; Bazen, 2005). Dimana ditemukan bahwa upah minimum sebagai variable utama penentu, dalam hal penyerapan tenaga kerja dan variabel dari sisi permintaan dan penawaran tenaga kerja sebagai variabel kontrol.

Berbeda dengan Pratomo (2010) menggunakan data individual microdata tahun 1989 sampai dengan 2003 mengemukakan bahwa meningkatnya upah minimum dapat mengurangi probability tenaga kerja untuk terserap dalam pasar tenaga kerja formal dan menigkatkan probability untuk dapat terserap di pasar tenaga kerja informal.

Selanjutnya dengan menggunakan data panel 26 provinsi yang ada di Indonesia dengan tahun yang sama, Pratomo (2011) menemukan bahwa upah minimum tidak memberikan dampak yang signifikan pada penyerapan tenaga kerja di Indonesia. Hal ini dikarenakan adanya 1) masih adanya compliance issue terhadap ketetapan upah minimum dan 2) penyerapan total tenaga kerja tidak mampu digmbarkan melalui upah minimum sebagai akibat masih tingginya proporsi tenaga kerja sektor informal di Indonesia. 
Adapun penyerapan tenaga kerja di Chili diteliti oleh Grau (2018) dengan fokus hanya pada tenaga kerja di sektor formal. Dengan menggunakan data individual tenaga kerja di usaha formal tahun 2008 sampai dengan 2012, ditemukan bahwa penyerapan tenaga kerja dan upah minimum memiliki hubungan yang lemah. Berbeda dengan model pasar tenaga kerja kompetitif, diyakini bahwa meningkatnya upah minimum dalam besaran yang moderat, tidak akan memberikan efek pengurangan tenaga kerja maupun pengangguran.

Berbeda dengan Raymundo (2016) berkenaan dengan penyerapan tenaga kerja formal dan informal, mengelompokan wilayah dengan upah tinggi dan rendah di Meksiko. Lebih lanjut, ditemukan bahwa tenaga kerja di wilayah dengan upah rendah cenderung menambah jam kerja. Selain itu probability tenaga kerja untuk bekerja di sektor informal ataupun menganggur ikut berkurang dengan meningkatnya upah minimum.

Pada konteks negara berkembang dengan compliance issue pada kebijakan upah mnimum sepeti Honduras, Gindling dan Terrell (2009) menemukan bahwa efek upah minimum hanya terjadi pada sektor formal. Hubungan antara upah minimum dan peningkatan upah rata - rata tenaga kerja ditemukan positif namun pada saat yang bersamaan mengurangi tingkat penyerapan tenaga kerja perusahaan khususnya pada level menengah dan besar.

Penelitian terkait hubungan antara pertumbuhan ekonomi dan penyerapan tenaga kerja juga telah banyak dilakukan dengan hasil yang cukup beragam. Pada konteks perekonomian Vietnam, Manh (2014) menemukan adanya keterkaitan kuat antara pertumbuhan ekonomi dan penyerapan tenaga kerja dengan tingkat elastisitas 1,71 . Kemudian Oloni (2013) menemukan bahwa pada konteks perekonomian Nigeria, pertumbuhan ekonomi belum mampu meningkatkan penyerapan tenaga kerja karena industri padat karya, tidak mendapat insentif dari proses pembangunan yang sudah dilakukan.

(Herman, 2011) dengan demikian, dari beberapa dialektika pandangan tersebut mengkonfirmasi bahwa respon pasar tenaga kerja nampaknya sangat beragam di beberapa negara, dimana terdapat pengaruh yang lemah antara pertumbuhan ekonomi dan penyerapan tenaga kerja di Uni Eropa. 


\section{METODE PENELITIAN / METHODS}

Penelitian ini menggunakan metode regresi dengan memanfaatkan data dari Badan Pusat Statistik Provinsi Jawa Timur dari tahun 2012 sampai dengan 2018. Dikarenakan tidak adanya publikasi terkait keadaan tenaga kerja, khusus pada tahun 2016 dilakukan interpolasi untuk memperkirakan data pada tahun amatan tersebut. Adapun persamaan yang digunakan untuk menjelaskan efek upah minimum, karakteristik demand-supply side labor, dan karakteristik wilayah terhadap penyerapan tenaga kerja industri mengadopsi penelitian Pratomo (2011) dengan persamaan dasar sebegai berikut:

$$
\ln E m p_{i t}=\alpha_{0}+\alpha_{l} \ln M W_{i t}+\Psi_{i t} X+\gamma_{i}+v_{t}+\varepsilon_{i t}
$$

di mana Emp sebagai variable endogen adalah jumlah angkatan dengan status bekerja pada wilayah i dan tahun t yang menggambarkan penyerapan tenaga kerja. Adapun variabel eksogen pada persamaan ini menggambarkan interaksi antara permintaan dan penawaran tenaga kerja. MW adalah upah minimum Kabupaten/Kota i dan tahun y; Vektor $\mathrm{X}$ merupakan variable kontrol untuk menggambarkan karakteristik penawaran tenaga kerja; y dan v merupakan variable kontrol yang menggambarkan karakteristik wilayah dan waktu.

Penelitian ini mengadopsi persamaan tersebut dengan mempertimbangkan karakteristik tenaga kerja industri di Jawa Timur. Selanjutnya, merujuk pada Pratomo (2015), persamaan dapat mempertimbangkan beberapa variable makro untuk menjelaskan kondisi permintaan tenaga kerja. Sehingga persamaan tersebut dimodifikasi sebagai berikut.

$$
\text { LnTKind }=\alpha_{0}+\beta_{1} \ln U M_{i t}+\beta_{2} \ln A K \_M_{-} u_{i t}+\beta_{3} \operatorname{lnPDRBInd}{ }_{i t}+\beta_{4} \mathrm{DID}_{i t}+\varepsilon_{i t}
$$

Di mana, TKind merupakan jumlah tenaga kerja yang bekerja di sektor industri di Jawa Timur; UM adalah tingkat upah minimum regional tiap kabupaten/kota di Jawa Timur, AK_Muda adalah jumlah angkatan kerja muda Kabupaten/Kota di jawa Timur, PDRBInd adalah produk domestik regional bruto di Kabupaten/Kota di Jawa Timur, dan DID adalah variable dummy untuk dominasi nilai tambah industri pada Kabupaten/Kota di jawa Timur. Untuk variabel dummy dihitung berdasarkan nilai rata - rata PDRB Industri di Jawa Timur, sehingga "0" adalah wilayah dengan rata - rata nilai PDRB industri yang berada di bawah rata - rata; dan 1 adalah wilayah dengan rata - rata nilai PDRB industri yang berada di atas rata - rata. 


\section{HASIL DAN PEMBAHASAN / DISCUSSION}

Uji spesifikasi model dilakukan untuk menetapkan model regresi data panel yang sesuai dengan persamaan yang digunakan. Hasil uji spesifikasi model dapat dilihat pada tabel 1, di mana didapatkan bahwa model terbaik adalah menggunakan FEM.

Tabel 1. Uji Spesifikasi Model Penyerapan Tenaga kerja Industri Prov. Jawa Timur

\begin{tabular}{ccc}
\hline Pengujian & Hasil & Kesimpulan \\
\hline Uji Chow & P value $<5 \%$ & FEM (Fixed Effect Model) \\
\hline Uji Hausmann & P value $<5 \%$ & FEM (Fixed Effect Model) \\
\hline VIF & $\begin{array}{c}\text { VIF LnUM }>10 \\
\text { VIF LnPDRBind }>10 \\
\text { VIF Ln_AKmuda }<10 \\
\text { VIF DID }<10\end{array}$ & $\begin{array}{c}\text { Diduga terddapat hubungan } \\
\text { antara variabel PDRBind dan UM }\end{array}$ \\
\hline $\begin{array}{c}\text { Wooldridge test for autocorrelation } \\
\text { in panel data }\end{array}$ & P Value $<5 \%$ & Terdapat masalah autokorelasi \\
\hline $\begin{array}{c}\text { Modified Wald test for groupwise } \\
\text { heteroskedasticity }\end{array}$ & P Value $<5 \%$ & $\begin{array}{c}\text { Terdapat masalah } \\
\text { heteroskedastisitas }\end{array}$ \\
\hline
\end{tabular}

Sumber: Hasil perhitungan mengunakan data BPS 2012 - 2018

Selanjutnya, dilakukan pengujian asumsi klasik sebagaimana tampak pada tabel 1. Diketahui bahwa terdapat masalah autokorelasi dan heteroskedastisitas. Untuk memperbaiki permasalahan tersebut, digunakan estimasi PCSE (Panel Corrected Standard error) dengan hasil yang dapat dilihat pada tabel 2 .

Adapun permasalahan multinolinieritas tidak mendapat perlakuan khusus untuk membuktikan bahwa dalam dalam persamaan penyerapan tenaga kerja terdapat hubungan diantara variabel bebas yakni upah minimum dan PDRB industri sebagaimana dampak dari kebijakan pengupahan. Selain itu, variabel tersebut diperlukan dalam persamaan untuk dapat menggambarkan penyerapan tenaga kerja di tengah tingginya kinerja industri.

Tabel 2 mengemukakan hasil pengujian persamaan penyerapan tenaga kerja. Pada model FEM diketahui bahwa hanya upah minimum yang mampu mempengaruhi penyerapan tenaga kerja industri di Jawa Timur. Namun berlawanan dengan model pasar tenaga kerja kompetitif, peningkatan upah minimum mampu meningkatkan pekerja yang bekerja di sektor Industri di Jawa Timur. 
Berkenaan dengan temuan upah minimun, arah variabel tersebut dapat dijelaskan melalui konsep pilihan tenaga kerja yang mengemukakan bahwa meningkatnya upah minimum dapat mendorong motivasi tenaga kerja untuk miningkatkan partisipasi tenaga kerja (Ehrenberg\&Smith, 2012). Lebih lanjut, hal tersebut dijelaskan melalui adanya dominasi subtitution effect yakni meningkatkan upah minimum pada tingkatan kuantitas maupun kualitas tertentu mampu mendorong partisipasi pekerja dalam pasar tenaga kerja.

Tabel 2. Output Hasil estimasi Model Penyerapan Tenaga kerja Industri Prov. Jawa Timur

\begin{tabular}{|c|c|c|c|}
\hline Variabel & $\begin{array}{l}\text { (1) } \\
\text { FEM }\end{array}$ & $\begin{array}{c}\text { (2) } \\
\text { PCSE }\end{array}$ & $\begin{array}{c}(3) \\
\text { PCSE dengan } \\
\text { Interaksi } \\
\end{array}$ \\
\hline Ln_AK_Muda & $\begin{array}{l}-1.61 \mathrm{e}-07 \\
(2.31 \mathrm{e}-07)\end{array}$ & $\begin{array}{l}-2.03 e-08 \\
(2.69 e-07)\end{array}$ & $\begin{array}{c}-5.30 \mathrm{e}-08 \\
(2.61 \mathrm{e}-07)\end{array}$ \\
\hline DID & $\begin{array}{c}0.155 \\
(0.186)\end{array}$ & $\begin{array}{c}-0.169 \\
(0.218)\end{array}$ & $\begin{array}{c}0.268 \\
(0.194)\end{array}$ \\
\hline LnUM & $\begin{array}{c}0.597 * * * \\
(0.0763)\end{array}$ & $\begin{array}{c}0.807 * * * \\
(0.295)\end{array}$ & $\begin{array}{c}0.880 * * * \\
(0.285)\end{array}$ \\
\hline Ln_PDRBind & $\begin{array}{l}-0.0325 \\
(0.0554)\end{array}$ & $\begin{array}{c}0.262 * * * \\
(0.0746)\end{array}$ & $\begin{array}{c}0.473 * * * \\
(0.0851)\end{array}$ \\
\hline Interaksi_UM_PDRDind & & & $\begin{array}{c}-1.92 \mathrm{e}-09 * * * \\
(2.76 \mathrm{e}-10)\end{array}$ \\
\hline Constant & $\begin{array}{c}2.842 * * \\
(1.140)\end{array}$ & $\begin{array}{l}-4.369 \\
(4.279)\end{array}$ & $\begin{array}{l}-8.337 * \\
(4.278)\end{array}$ \\
\hline $\begin{array}{l}\text { Observations } \\
\text { Number of cross }\end{array}$ & $\begin{array}{c}266 \\
38\end{array}$ & $\begin{array}{c}266 \\
38\end{array}$ & $\begin{array}{c}266 \\
38\end{array}$ \\
\hline
\end{tabular}

Note:

Standard errors in parentheses $* * * p<0.01, * * p<0.05, * p<0.1$

Sumber: Hasil perhitungan mengunakan data BPS $2012-2018$

Meskipun demikian, gagasan tersebut masih cenderung lemah menyusul adanya ketimpangan antara wilayah terkait upah minimum dan IPM seperti terlihat pada gambar 5 . Terlihat bahwa masih adanya pengelompokan wilayah yang memiliki IPM tinggi namun dengan tingkat upah minimum yang rendah sehingga opportunity cost untuk menambah partisipasi kerja masih relatif tinggi.

Berkenaan dengan temuan upah minimun, arah variabel tersebut dapat dijelaskan melalui konsep pilihan tenaga kerja yang mengemukakan bahwa meningkatnya upah minimum dapat mendorong motivasi tenaga kerja untuk miningkatkan partisipasi tenaga kerja (Ehrenberg dan Smith, 2012). Lebih lanjut, hal tersebut dijelaskan melalui adanya dominasi subtitution effect yakni meningkatkan upah minimum pada tingkatan kuantitas maupun kualitas tertentu mampu mendorong partisipasi pekerja dalam pasar tenaga kerja. 
Selanjutnya, variabel PDR Bind mampu menunjukan bahwa kuatnya industri mampu mendorong penyerapan tenaga kerja (lihat tabel 2). Sebagaimana hasil estimasi, meningkatnya output industri mampu menciptakan lapangan kerja sehingga penyerapan tenaga kerja akan semakin meningkat. Hal tersebut sesuai dengan temuan Manh dkk (2014) yang mengestimasi hubungan antara pertumbuhan ekonomi dan penyerapan tenaga kerja di mana ditemukan bahwa kinerja ekonomi yang tinggi mampu menciptakan lapangan kerja sehingga kesempatan angkatan kerja untuk terserap semakin tinggi.

Gambar 5. Sebaran Kabupaten/Kota di Jawa Timur Berdasarkan Upah Minimum dan IPM (Indeks Pembangunan Manusia), tahun 2017

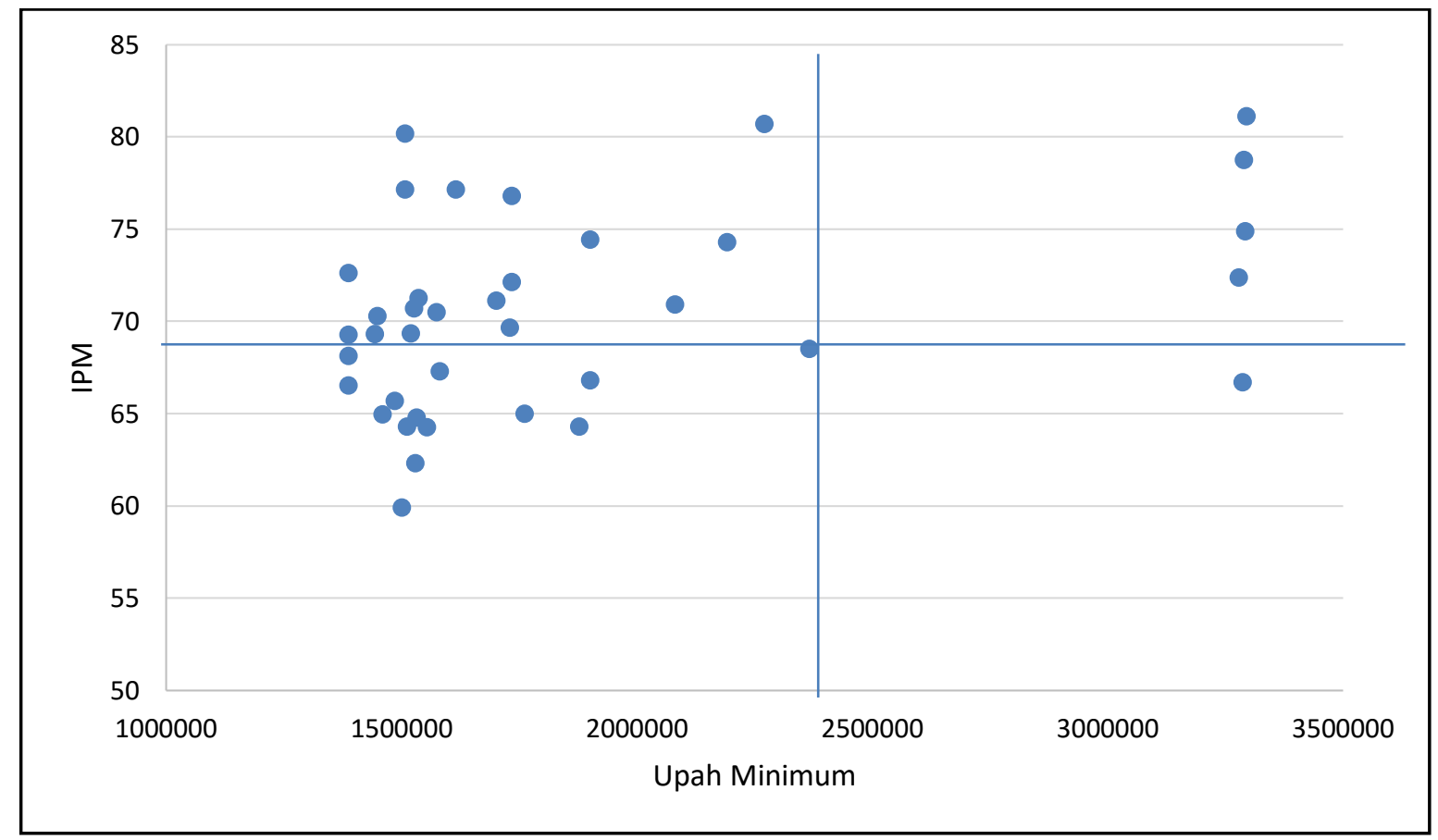

Sumber: BPS Prov. Jawa Timur, data diolah (2019).

Lebih lanjut, melalui temuan antara upah minimum, PDRB Industri dan penyerapan tenaga kerja, penelitian ini berupaya membuktikan terdapat dual-effect di mana peningkatan output industri di satu sisi mampu menyerap lebih banyak tenaga kerja; namun di sisi lain, peningkatan output industri juga mampu mengurangi penyerapan tenaga kerja di sektor tersebut. Hal ini dikarenakan terjadi multikolinieritas pada model yang terjadi pada variabel PDRBind dan UM.

Sebagaimana tampak pada gambar 6, terdapat kecenderungan wilayah dengan PDRB rendah memiliki upah minimum rendah; begitu pula sebaliknya. Untuk membuktikan adanya saling pengaruh antara upah minimum dan PDRB Industri di Jawa Timur, penelitian 
Atu Bagus Wiguna. Penyerapan Tenaga Kerja Industri ...

ini melakukan simulasi variabel interaksi antara upah minimum dan PDRB Industri. Ditemukan bahwa, terdapat hubungan yang negatif dan signifikan diantara kedua variabel tersebut dengan penyerapan tenaga kerja (lihat tabel 3). Sesuai dengan model standar pasar tenaga kerja, meningkatnya PDRB industri akan diikuti oleh upah minimum yang pada giliran selanjutnya dapat mengurangi penyerapan tenaga kerja.

Gambar 6. Sebaran Kabupaten/Kota di Jawa Timur Berdasarkan Upah Minimum dan PDRB Industri, tahun 2017

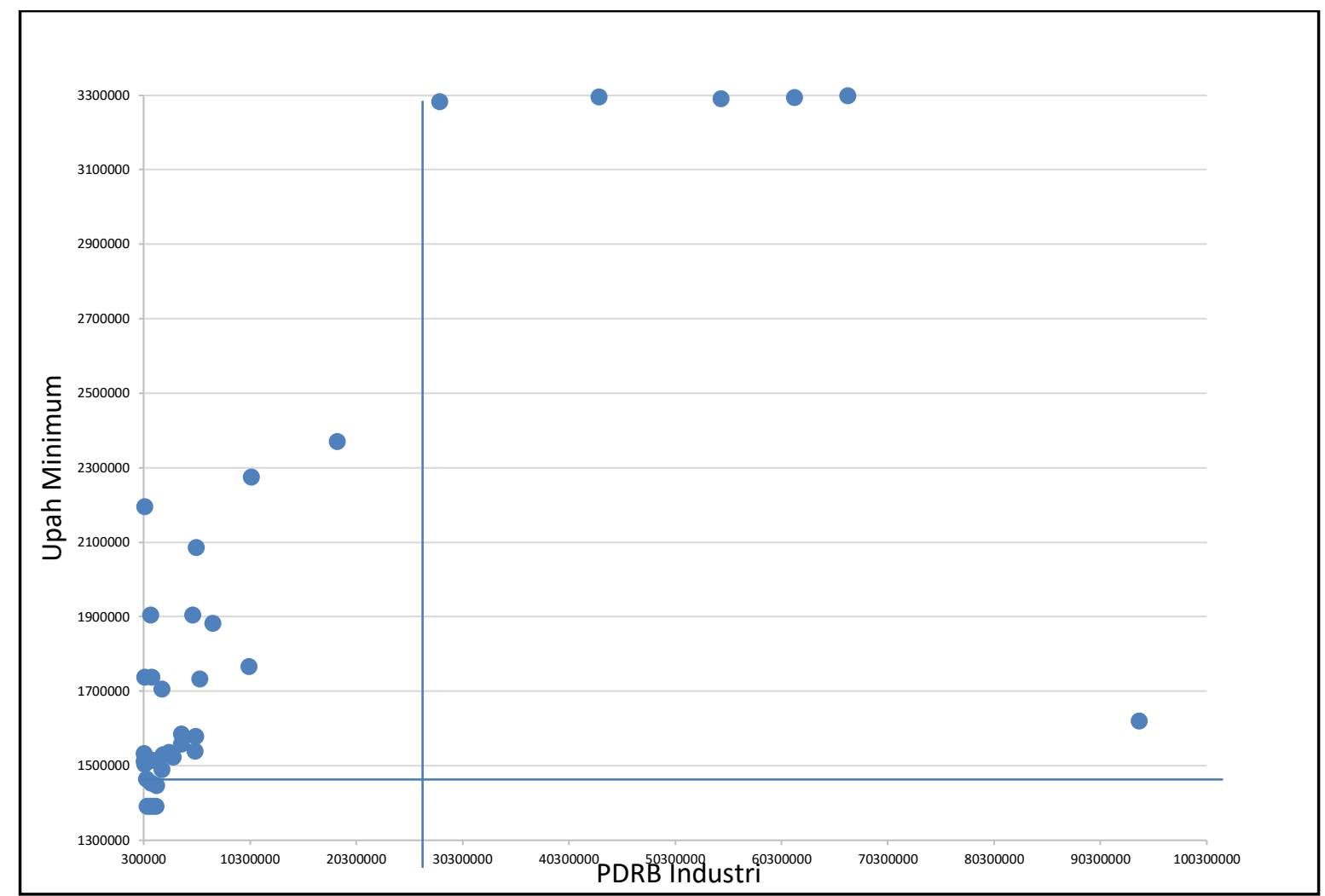

Sumber: BPS prov. Jawa Timur, data diolah (2019)

Temuan ini juga sesuai dengan Bauducco dan Janiak (2018) yang menemukan bahwa sesungguhnya pada peningkatan upah minimun terdapat 2 efek yang terjadi secara bersamaan. Pertama adalah efek capital demand di mana perusahaan cenderung menambah faktor modal sebagai efek meningkatnya upah minimum. Di sisi lain, terdapat pula efek rent appropriation di mana perusahaan cenderung menambah partisipasi tenaga kerja yang menerima upah minimum untuk mengantisipasi penggunaan faktor modal yang bertambah. 
Selanjutnya, masih pada konteks permintaan tenaga kerja, meskipun PDRB industri menjadi elemen penting dalam penyerapan tenaga kerja industri namum tampak bahwa terdapat fenomena pergeseran industri yang membuat dominasi industri di suatu wilayah tidak mampu menyerap tenaga kerja secara optimal. Hal tersebut sesuai dengan estimasi variabel DID (Dominasi Industri) yang menunjukan pengaruh yang tidak signifikan terhadap penyerapan tenaga kerja industri.

Gambar 7. Tren Peningkatan Unit Usaha Industri Beberapa Wilayah di Provinsi Jawa Timur

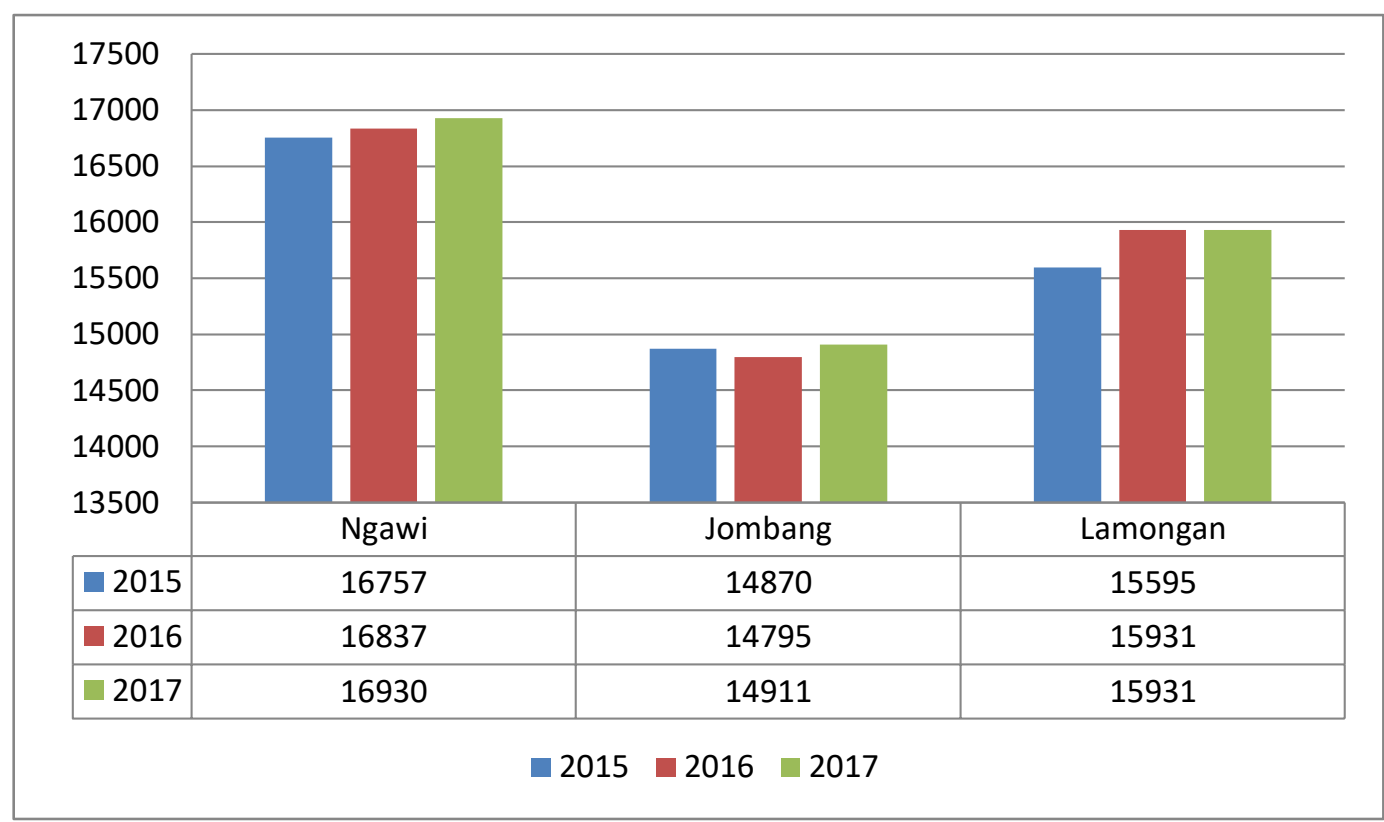

Sumber: BPS prov. Jawa Timur, data diolah (2019)

Gambar 7 menunjukan adanya pemusatan peningkatan jumah unit usaha industri di beberapa wilayah di Jawa Timur. Dalam hal ini, industri cenderung merelokasi usaha menuju wilayah dengan tingkat upah minimum yang relatif lebih rendah untuk menekan biaya produksi. Terdapat peningkatan jumlah unit usaha di ketiga wilayah yakni Kabupaten Ngawi, Kabupaten Jombang, dan Kabupaten Lamongan. Ketiga wilayah memiliki tingkat upah minimum yang lebih rendah dibandingkan wilayah industri yang dominan di Jawa Timur seperti Kota Surabaya, Kabupaten Sidoarjo, Kabupaten Mojokerto, Kabupaten Pasuruan dan Kabupaten Gresik.

Terakhir, sebagai variabel kontrol untuk menggambarkan kondisi penawaran tenaga kerja, jumlah angkatan kerja muda yang meningkat diekspektasikan mampu meningkatkan penyerapan tenaga kerja Jawa Timur. Hal tersebut dikarenakan kualitas pembangunan 
manusia yang terus membaik serta oleh kelompok usia muda pada struktur angkatan kerja. Namun jumlah angkatan kerja tidak mampu menjelaskan kondsi penawaran dan penawaran tenaga kerja di Jawa Timur.

\section{KESIMPULAN / CONCLUSION}

Penelitian ini berupaya menganalisi faktor - faktor yang mempengaruhi penyerapan tenaga kerja di Jawa Timur, khususnya di era peningkatan kinerja industri tahun 2012 sampai dengan 2018. Dengan menggunakan persamaan berdasakan Pratomo (2011), penyerapan tenaga kerja industri dapat dijelaskan oleh upah minimum dan peningkatan output industri.

Beberapa hal yang dapat disimpulkan melalui hasil temuan penelitian ini adalah pertama, Peningkatan PDRB industri di Jawa Timur mampu menciptakan lapangan pekerjaan sehingga meningkatkan penyerapan tenaga kerja industri; namun wilayah Kabupaten / Kota di Jawa Timur dengan PDRB Industri yang tinggi cenderung diikuti dengan tingkat upah minimum yang tinggi pula sehingga dapat mengurangi penyerapan tenaga kerja di wilayah tersebut.

Kedua, dominasi industri di beberapa wilayah kabupaten / Kota di Jawa Timur tidak menjamin meningkatkan penyerapan tenaga kerja industri. Hal tersebut dijelaskan oleh fenomena meningkatnya shifting lokasi industri yang semula berada di wilayah industri dominan (Kota Surabaya, Kabupaten Sidoarjo, Kabupaten Mojokerto, Kabupaten Pasuruan dan Kabupaten Gresik) kemudian pindah ke beberapa lokasi yang memiliki tingkat PDRB dan Upah Minimum yang rendah seperti Kabupaten Ngawi, Jombang dan Lamongan.

Implikasi dari hasil penelitian ini menunjukan bahwa saat ini kebijakan pengupahan membuat upah minimum menjadi instrument yang lemah dalam rangka menggambarkan perekonomian daerah khususnya mengenai penyerapan tenaga kerja. Hal tersebut seiring dengan kebijakan pengupahan di Indonesia melalui Peraturan Pemerintah No 78 Tahun 2015 tentang pengupahan yang menetapkan upah minimum dengan mempertimbangkan Produk Domestik Bruto dan inflasi. Dengan kata lain, kinerja perekonomian daerah dapat menjadi instrument pengukuran utama mengenai kondisi tenaga kerja di suatu wilayah. Oleh sebab itu, penelitian yang akan datang dapat fokus pada perbedaan efek upah minimum sebelum dan sesudah adanya peraturan pemerintah yang dimaksud dengan mempertimbangkan perbedaan karakteristik wilayah di Indonesia. 
Untuk mendorong penyerapan tenaga kerja industri, beberapa usulah arah prioritas kebijakan yang perlu dilakukan adalah dengan 1) Untuk wilayah dengan PDRB tinggi, diperlukan peningkatan kualitas tenaga kerja industri untuk meminimalisir terjadinya shifting penggunaan tenaga kerja oleh modal; 2) Untuk wilayah dengan PDRB rendah, percepatan pembangunan kawasan industri perlu dipercepat agar dapat menampung tren relokasi dan arus perpindahan tenaga kerja industri.

\section{DAFTAR PUSTAKA / REFERENCES}

Bauduccoa, Sofía dan Alexandre Janiak. 2018. The macroeconomic consequences of raising the minimum wage: Capital accumulation, employment and the wage distribution. European Economic Review 101, 57-76.

Bazen, Stephen. 2005. Do Minimum Wages Have a Negative Impact on Employment in the United States? Économie publique 17, No 2.

Borjas, George J. 2016. Labor Economics. New York: McGraw-Hill Education.

Card, D. dan A. Krueger. 1994. Minimum Wages and Employment: a Case Study of the FastFood Industry in New Jersey and Pennsylvania, American Economic Review, Vol. 84, 772-793.

Ehrenberg, Ronald G dan Robert S Smith. 2012. Modern Labor Economics: Theory and Public Policy. New York: Pearson Education.

Gindling, T.H. and K. Terrell. 2009. Minimum wages, wages and employment in various sectors in Honduras", Labour Economics, vol. 16, No. 3.

Grau, Nicolás, Jorge Miranda, dan Esteban Puentes. 2018. The Effects of the Minimum Wage on Employment and Wages. Serie De Documentos De Trabajo No. 466, pp. 1 64.

Herman, E. 2011. The Impact of Economic Growth Process on Employment in European Union Countries", Romanian Economic Journal, 14(42): 47-67.

Mạnh, Phạm Hồng, Nguyễn Văn Ngọc, Hạ Thị Thiều Dao. 2014. Relationship between Economic Growth and Employment in Vietnam. JED No.222.

Marimpi, Maria dan Pierre Koning. 2018. Youth minimum wages and youth employment. IZA Journal of Labor Policy 7: 5.

Nicholson, Walter dan Christopher Snyder. 2010. Intermediate Microeconomics and Its Application. Amerika Serikat: South-Western Cengage Learning. 
Oloni, Elizabeth Funlayo. 2013. The Impact of Economic Growth on Employment in Nigeria. International Business and Management, Vol. 6, No. 1.

Pratomo, Devanto S. 2010. The Effects Of Changes in Minimum Wage On Employment in The Covered And Uncovered Sectors In Indonesia. Journal of Indonesian Economy and Business Vol 25, Number 3, 278 - 292.

Pratomo, Devanto S. 2011. The Effects of Changes in Minimum Wage on Employment in Indonesia: Regional Panel Data Analysis. International Research Journal of Finance and Economics 1450-2887 Issue 62.

Pratomo, Devanto S. 2015. The analysis of underemployment in Indonesia: determinants and its implication. Procedia - Social and Behavioral Sciences 211, 528 - 532.

Raymundo M. Campos Vázquez, Gerardo Esquivel dan Alma S. Santillán Hernández. 2016. The impact of the minimum wage on income and employment in Mexico. CEPAL Review, No 122. 